\title{
Lectotypification of two names in the genus Ipomoea (Convolvulaceae)
}

\author{
Shimpale, V.B. ${ }^{1 *}$, Kattee Amrapali, V. ${ }^{1}$ and Mayur D. Nandikar ${ }^{2}$ \\ 'Department of Botany, The New College, Kolhapur, Maharashtra - 416 012, India \\ ${ }^{2}$ Naoroji Godrej Centre for Plant Research, 431 Lawkim Campus, Shindewadi, \\ Post- Shirwal, Satara Dist., Maharashtra - 412 801, India \\ *E-mail: shimpale@yahoo.com
}

\begin{abstract}
The names Ipomoea clarkei Hook.f. and I. barlerioides (Choisy) Benth. ex C.B. Clarke are lectotypified.
\end{abstract}

Keywords: Convolvulaceae, Ipomoea barlerioides, Ipomoea clarkei, lectotypification

\section{Introduction}

The genus Ipomoea L. is one of the dominant genera in the family Convolvulaceae with $c .600$ species distributed in tropical and warm temperate regions of the world (Mabberley, 2017). About 63 species are known from India (Shimpale et al., 2014). In the course of taxonomic studies on the genus Ipomoea in India, it has been found that I. clarkei and $I$. barlerioides are yet to be typified. Hence lectotypes are selected according to Art. 9.3 of ICN (Turland et al., 2018).

Ipomoea barlerioides (Choisy) Benth. ex C.B. Clarke in Hook.f., Fl. Brit. India 4: 201. 1883.

Aniseia barlerioides Choisy, Convolv. Orient. 6: 484. 1834.

Lectotype (designated here): INDIA, Uttar Pradesh, 17.04.1814, s.coll. Wall. Cat. No. 2256.1 [B] (K001115497, digital image!). Syntypes: Sukanagar, 4.5.1810, Herb Hamilton, Wall., Numer. List 2256 B: K (K001115496, digital image!); Kumaon, s.d. R., Blinkworth, Wall. Cat. No. 1382 (K001112984, digital image!); Mysore, s.d. Buchanan s.n. (BM000927905, digital image!).

Fig. 1

Note: Choisy (1834) within the protologue of $A$. barlerioides cited "(V.S. ex Wall., et H.Br. Mus.) Hab. India (Gorackpur, Sukanagar, Kamaon, Mysore)". The different localities are associated with the Wall., Numer. List 1382 and 2256. The collections from the aforementioned localities are to be considered as syntypes. We have chosen (K001115497) as the lectotype because the specific epithet 'barlerioides' was first used in Wall., Numer. List 2256.

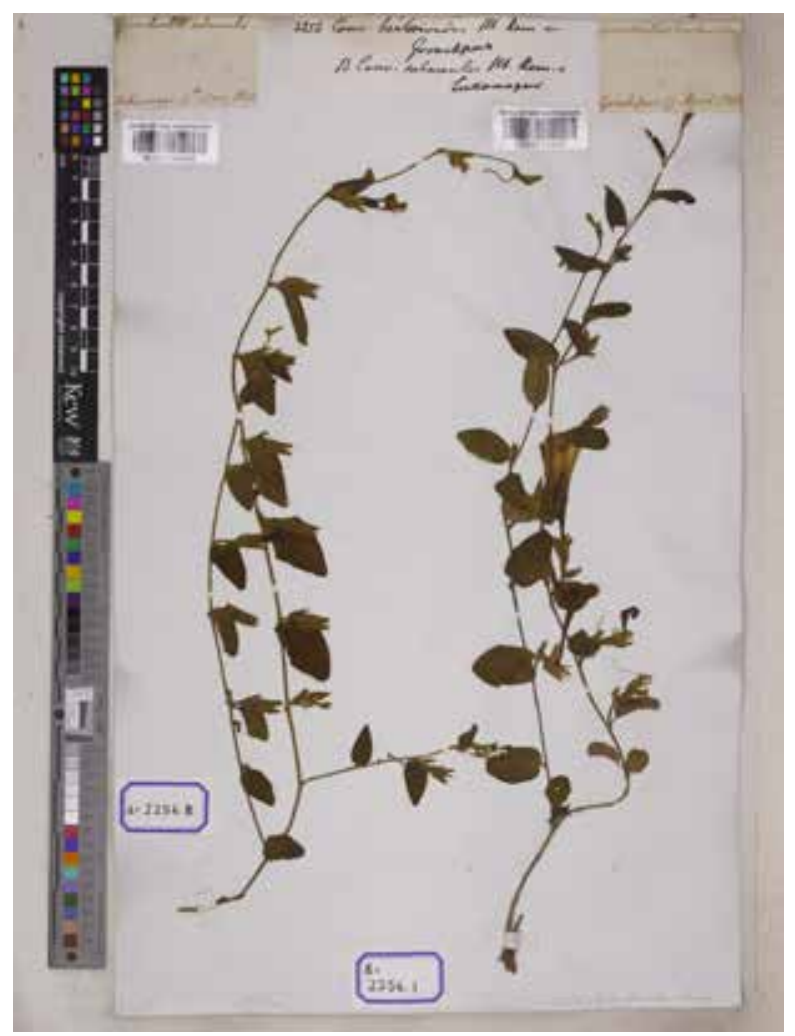

Fig. 1: Lectotype of Ipomoea barlerioides (Choisy) Benth. ex C.B. Clarke (Wall., Numer. List 2256: K001115497) [@ The Board of Trustees of the Royal Botanic Gardens, Kew. Reproduced with the consent of the Royal Botanic Gardens, Kew] 
Ipomoea clarkei Hook.f., Fl. Brit. India 4: 734. 1885.

I. stocksii C.B. Clarke in Hook.f., Fl. Brit. India 4: 207. 1883, non Clarke (1883: 204).

Lectotype (designated here): Malabar, Concan \& c. s.d., Stocks s.n. (K000830816, digital image!). syntype: Malabar, Concan \& c., s.d., Law s.n. (K001081777, digital image!).

Fig. 2

Note: Clarke (1883) published I. stocksii based on the collection of Stocks from Malabar. Clarke (1883) described a different species with the same name based on collections by Stocks, Law \& c. from Malabar and Concan. Hooker (1885) considered $I$. stocksii (1883) as a later homonym and provided the new name I. clarkei.

There are two relevant specimens at K (K000330816 and K000330817) of which we have designated K000830816 as the lectotype because the sheet has annotation by Clarke and matches with protologue.

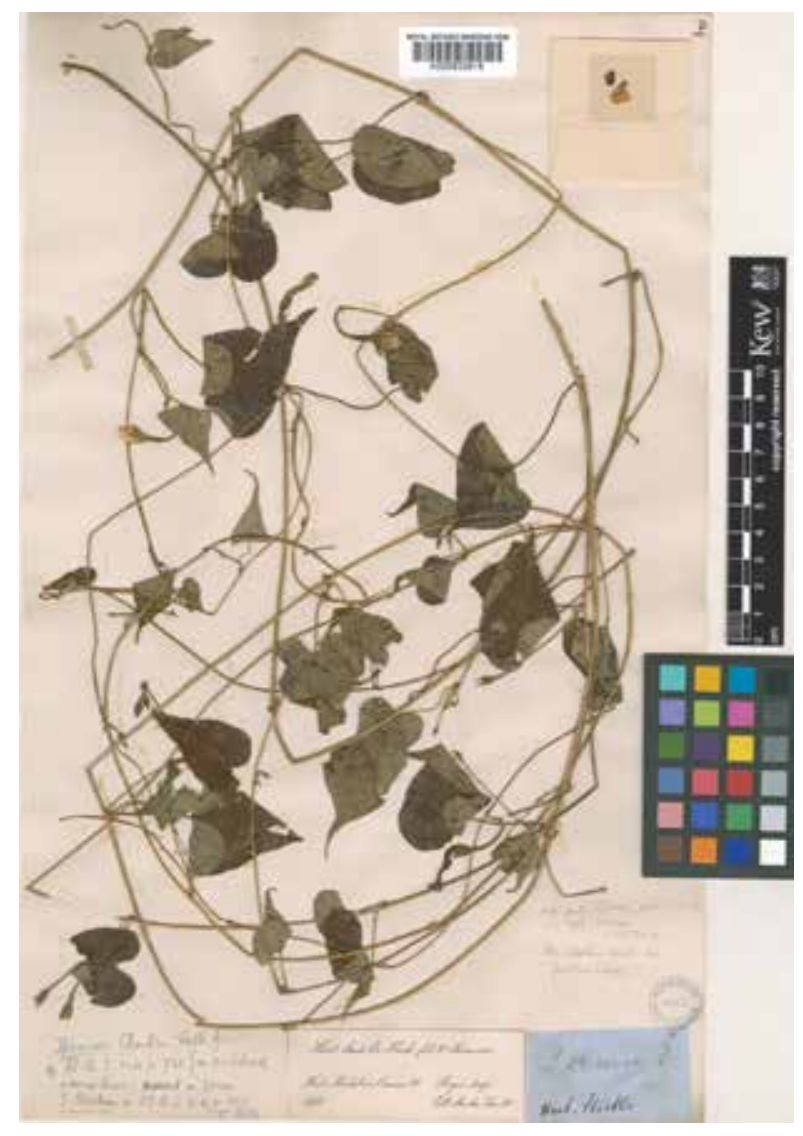

Fig. 2: Lectotype of Ipomoea clarkei Hook.f. (Stock s.n. K000830816) [@ The Board of Trustees of the Royal Botanic Gardens, Kew. Reproduced with the consent of the Royal Botanic Gardens, Kew]

\section{Acknowledgements}

Authors are thankful to the Principal, The New College, Kolhapur, to the Director, NGCPR, Shirwal for facilities and Board of Trustees of Royal Botanic Garden, Kew, for permission to publish the images of the types.

\section{Literature Cited}

Choisy, J.D. 1834. Convolvulaceae Orientales. Memoires de la Sociètè de Physique et d' Histoire Naturelle de Geneve. p. 102.

Clarke, C.B. 1883. Convolvulaceae. In: Hooker, J.D. (Ed.), Flora of British India. Vol. 4. L. Reeve \& Co., London. p. 201.

Hooker, J.D. 1885. Additions and corrections. In: Flora of British India. Vol. 4. L. Reeve \& Co., London. pp. 733-734.

Mabberley, D.J. 2017. The Plant - Book: A portable dictionary of plants, their distribution and uses. Fourth Edition. Cambridge University Press, Cambridge, UK. pp. 466-467.

Shimpale, V.B., Kare, M.A., Londhe, D.K. \& A.S. Bhuktar 2014. On the occurrence of Ipomoea tenuipes (Convolvulaceae) in India. Rheedea 24(2): 117-119.

Turland, N.J., Wiersema, J.H., Barrie, F.R., Greuter, W., Hawksworth, D.L., Herendeen, P. S., Knapp, S., Kusber, W.-H., Li, D.-Z., Marhold, K., May, T.W., McNeill, J., Monro, A.M., Prado, J., Price, M.J. \& G.F. Smith (Eds.) 2018. International Code of Nomenclature for algae, fungi, and plants (Shenzhen Code). Regnum Vegetabile 159. Koeltz Botanical Books, Glashütten. DOI https://doi.org/10.12705/ Code.2018.

Wallich, N. 1830-1832. A Numerical list of dried specimens of plants in the East India Company's Museum, collected under the superintendence of Dr. Wallich of the Company's Botanical Garden at Calcutta. London. p. 67.
Received: 08.05.2017

Revised and Accepted: 10.06.2018 